\section{Primary Health Care}

\section{Mavis L. Arthur and Jo M.M. Goddard}

Primary Health Care is a concept which has been receiving increasing attention as more and more authorities are questioning the role of curative medicine in improving the health of the population and in increasing life expectancy.

Predominantly curative services, it is at last realised, do not produce wellness. Health is determined by healthy living which includes good food, clean water, unpolluted air and good housing, both in the rural and urban context. Becaușe the World Health Organisation and its member states have recognised this, the International Conference on Primary Health Care held in Alma Ata in 1978 expressed the need for urgent action by all governments, all health and development workers and the world community at large, to protect and promote the health of all the people of the world.

It declared, among its 22 resolutions: . . health, which is a state of complete physical, mental and social, wellbeing and not merely the absence of disease or infirmity, is a fundamental human right and . . . the attainment of the highest possible level of health is a most important world-wide social goal, whose realisation requires the action of many social and economic sectors in addition to the health sector.

It goes on to say: Primary health care is essential health care based on practical, scientifically sound and socially acceptable methods and technology, made universally available to individuals and families in the community through their full participation and at a cost that the community and country can afford to maintain at every stage of their development in the spirit of self-reliance and self-determination.

Primary health care forms an integral part, both of the country's health system and of the overall social and economic development of the community. It is the first level of contact of individuals, the family and the community with the nation's health system. It brings health as close as possible to where people live and work and constitutes the first element of a continuing health care process.

Dr Halfdan Mahler, Director General of WHO, sees primary health care as a system which will include at least:

- promotion of proper nutrition;

- the development of adequate housing;

- safe water and basic sanitation;

\section{Primêre Gesondheidsorg}

\author{
Mavis L. Arthur en Jo M.M. Goddard
}

Primêre gesondheidsorg is ' $\mathrm{n}$ begrip wat ál meer aandag geniet namate al meer owerhede die rol van kuratiewe geneeskunde in die verbetering van die bevolking se gesondheid en die verhoging van lewensverwagting bevraagteken.

Uiteindelik word daar besef dat oorwegend kuratiewe dienste nie gesond wees bewerkstellig nie. Gesondheid word deur 'n gesonde lewenswyse bepaal, wat insluit: goeie kos, suiwer water, onbesoedelde lug en goeie behuising - sowel op die platteland as in die stad. Omdat die Wêreldgesondheidsorganisasie en sy lidstate dit besef, het die Internasionale Konferensie vir Primêre Gesondheidsorg in 1978 in Alma Ata die behoefte uitgespreek aan dringende optrede deur alle regerings, gesondheidspersoneel en ontwikkelingshelpers en die groot wêreldgemeenskap, ten einde die gesondheid van al die volke van die wêreld te beveilig en te bevorder.

In een van sy 22 resolusies word verklaar dat gesondheid, wat 'n toestand van algehele fisiese, geestelike en maatskaplike welstand is en nie net die afwesigheid van siekte of ongesteldheid nie, een van die mens se fundamentele regte is en . . om die hoogs moontlike vlak van gesondheid te bereik, is die belangrikste maatskaplike doel dwarsoor die wêreld -- die verwesenliking waarvan optrede deur talle maatskaplike en ekonomiese sektore, behalwe dié van die gesondheidsektor, vereis.

Daar word verder gesê: primêre gesondheidsorg is noodsaaklike gesondheidsorg wat op praktiese, wetenskaplik betroubare en maatskaplik aanvaarbare metodes en tegnologie gegrond is en wat - deur hulle volle deelname, en teen 'n prys wat die gemeenskap en land kan bekostig om in elke stadium van hulle ontwikkeling, in 'n gees van selfvertroue en selfbeskikking vol te hou - universeel aan individue en gesinne in die gemeenskap beskikbaar gestel word.

Primêre gesondheidsorg vorm 'n integrale deel sowel van die land se gesondheidstelsel as van die algemene maatskaplike en ekonomiese ontwikkeling van die gemeenskap. Dit is die eerste vlak waarop die individu, die gesin en die gemeenskap met die land se gesondheidstelsel in aanraking kom. Dit bring gesondheid so naby moontlik aan waar mense leef en werk, en is die eerste element in 'n voortgesette proses van gesondheidsorg.

Dr. Halfdan Mahler, direkteur-generaal van die WGO, beskou primêre gesondheidsorg as 'n stelsel wat ten minste die volgende insluit:

- bevordering van behoorlike voeding;

- toereikende behuising;

- veilige water en basiese sanitasie; 
- maternal and child care, including family planning and immunisation against the major infectious diseases;

- prevention and control of locally endemic diseases;

- education about prevailing health problems and ways of preventing them;

- appropriate treatment for common diseases and injuries.

Dr J.W. Bodenstein of the South African department of Health, Welfare and Pensions, says that primary health care would include population access to, and satisfaction with, a variety of required and integrated health and community services covering:

\section{Preventive and Promotive Activities}

- maternal and child health, including family planning;

- immunisation;

- nutritional education;

- endemic disease control;

- basic sanitation and environmental control;

- health education:

\section{Treatment Activities e.g.}

- emergency care;

- treatment of minor illnesses;

- treatment of prevalent endemic diseases;

- referral of patients to advanced treatment facilities;

\section{Community Related Activities e.g.}

- promotion of food production;

- development of basic communication facilities and means of transportation;

- promotion of cultural activities for the transmission of ideas related to health and well-being.

In addition, in terms of the Health Act 63 of 1977, rehabilitation services are legislated for which will complete the sequence of primary, secondary and tertiary prevention when they become fully operative.

One commonly hears health workers (doctors, nurses, nursing administrators, and others) talking about primary health care and referring only to the diagnosis and treatment of disease conditions. This gives the wrong impression of what primary health care really involves, or should involve.

Looking at the World Health Organisation's definition of primary health care, one becomes aware that the curative aspect forms only a part of the whole concept. The major aspects involve basic promotive, preventive and rehabilitative health measures. In Dr Bodenstein's concept of primary health care, we again find that promotive and preventive activities take precedence.

Thus, the term primary health care implies all the promotive, preventive, curative and rehabilitative services necessary to ensure the health of the whole popu-
- moeder- en kindersorg, wat gesinsbeplanning en immunisering teen die belangrike aansteeklike siektes insluit;

- voorkoming en beheer van plaaslike endemiese siektes;

- voorligting oor die heersende gesondheidsprobleme en maniere om hulle te voorkom;

- die regte behandeling vir algemene siektes en beserings.

Dr. J.W. Bodenstein van die Suid-Afrikaanse Departement Gesondheid. Welsyn en Pensioene sê dat primêre gesondheidsorg die bevolking toegang sal verleen tot en hulle tevredenheid sal bied ten opsigte van 'n verskeidenheid noodsaaklike en geïntegreerde gesondheids- en gemeenskapsdienste wat die volgende behels:

\section{Voorkomende en bevorderende werksaamhede}

- gesondheid van moeder en kind, gesinsbeplanning inbegrepe;

- immunisering;

- voedingsvoorligting;

- beheer oor endemiese siektes;

- beheer oor sanitasie en die omgewing;

- gesondheidsvoorligting.

Behandelingswerksaamhede, bv.

- bevordering van voedselproduksie;

- uitbou van basiese kommunikasiefasiliteite en vervoermiddels;

- bevordering van kultuurwerksaamhede vir die oordra van gedagtes wat met gesondheid en welsyn verband hou.

Daarbenewens, volgens die Wet op Gesondheid 63 van 1977, word wette vir rehabilitasiedienste gemaak wat, as hulle ten volle in werking is, die opeenvolging van primêre, sekondêre en tersiêre voorkoming sal voltooi.

'n Mens hoor dikwels dat gesondheidswerkers (geneeshere, verpleegsters, verpleegadministrateurs en ander) oor primêre gesondheidsorg praat en net na die diagnose en behandeling van siektetoestande verwys. Dit gee 'n verkeerde indruk van wat primêre gesondheidsorg werklik behels of behoort te behels.

As die Wêreldgesondheidsorganisasie se definisie van primêre gesondheidsorg bekyk word, besef 'n mens dat die kuratiewe aspek net 'n deel van die hele konsep vorm. Die belangrikste aspek behels bevorderende, voorkomende en rehabiliterende gesondheidsmaatreëls. Uit dr. Bodenstein se opvatting van primêre gesondheidsorg blyk weer eens dat bevorderende en voorkomende werksaamhede voorkeur kry. Die benaming primêre gesondheidsorg impliseer al die bevorderende, voorkomende, kuratiewe en rehabiliterende dienste wat nodig is om die gesondheid van die hele bevolking te verseker en 'n mens moet oppas om nie een van die aspekte ten koste van die ander te beklemtoon nie.

Gesien die Wêreldgesondheidsorganisasie se interpretasie van primêre gesondheidsorg, moet sekere fun- 
lation, and one must be very careful not to emphasise any one of these aspects to the detriment of the others.

In the light of the World Health Organisation's interpretation of primary health care, certain fundamental concepts, as outlined by Dr Mahler, need to be examined. These are:

- the community itself must play the principal role in health care activities. This implies its full involvement in the planning, operation and control of primary health care. The skills that community health workers require and their consequent training will vary widely throughout the world, and indeed, even in different parts of the same country, if developed and developing areas exist side by side. Whatever their level of skill, it is important that community health workers understand the real health needs of the community they serve and that they gain the confidence and active backing of the people;

- health is not a separate entity, but an integral part of national development. Primary health care will therefore have the best chance of succeeding if it is included at all levels as part of the overall development plan of any government;

- health care has to be equitably spread. Planners should not be asking To how many people can we provide good health care? but rather Given these resources, how can we use them to provide health care for everyone? In too many countries today $80 \%$ of the health budget is still spent on only $20 \%$ of the population, and there is wide-spread dissatisfaction with health care throughout the world;

- national resources are needed to support primary health care. In many countries such resources need to be increased and existing resources redistributed so as to provide for technical knowledge, guidance and supervision, training of personnel, supplies, transport, communications, maintenance, solving specific problems and care of patients referred to other levels of the health care system. In short, the presence of a supportive health service infrastructure is fundamental to and essential for the effective operation of a primary health care system.

If the World Health Organisation's plan of health for all by the year 2000 is to become a reality, nurses, along with other health personnel, must change their attitude with regard to the meaning of the term primary health care. They must be prepared to modify their ideas so as to include primary, secondary and tertiary prevention of disease in all areas of their work.

\section{References}

1. Bodenstein. J.W. Primary health care - its principles and some of its implications in ou South African development context. S A Journal of Nursing Vol 42 No 11. Nov 1975

2. De Beer, J. Primary health care. Paper presented at the Congress of the Medical Association of South Africa. July 1981.

3. Mahler. H. Primary Health Care - Justice in Health. World Health May 1978.

4. Skeet, M. Nursing Overseas - No nurse is an island. Nursing Mirror. Vol 151 No 25. Dec $18 / 25,1980$. damentele begrippe, soos dr. Mahler hulle skets, ondersoek word. Hier volg hulle:

- die gemeenskap moet self die hoofrol in gesondheidsorgwerksaamhede speel. Dit behels sy algehele betrokkenheid by die beplanning, werksaamhede in verband met en beheer oor primêre gesondheidsorg. Die vaardighede wat gemeenskapsgesondheidswerkers nodig het en die gevolglike opleiding daarvoor, sal grootliks deur die wêreld en selfs in verskillende dele van dieselfde land verskil waar ontwikkelende en onontwikkelende gebiede naas mekaar lê. Wat die vlak van hulle vaardighede ook mag wees, is dit belangrik dat gemeenskapsgesondheidswerkers die werklike gesondheidsbehoeftes van die gemeenskap wat hulle dien, moet begryp en dat hulle die vertroue en daadwerklike steun van die mense moet hê;

- gesondheid is nie 'n afsonderlike entiteit nie, maar 'n noodsaaklike deel van die nasionale ontwikkeling. Primêre gesondheidsorg het dus die beste kans op sukses as dit op alle vlakke deel van die globale ontwikkelingsplan van 'n regering vorm;

- gesondheidsorg moet regverdig versprei word. Beplanners moet nie vra: aan hoeveel mense kan ons gesondheidsorg verskaf nie, maar: hoe kan ons die bronne wat ons het, gebruik om gesondheidsorg aan almal te verskaf? Daar is vandag nog te veel lande waar $80 \%$ van die gesondheidsbegroting aan net $20 \%$ van die bevolking bestee word en daar is algemene ontevredenheid met gesondheidsorg oor die hele wêreld;

- daar is nasionale bronne nodig om primêre gesondheidsorg te steun. In talle lande moet sulke bronne aangevul en bestaande bronne herversprei word om voorsiening te maak vir tegniese kennis, leiding en toesig, personeelopleiding, voorrade, vervoer, kommunikasie, die oplossing van bepaalde probleme en die versorging van pasiënte wat na ander vlakke van die gesondheidsorgstelsel verwys is. Kortliks, 'n ondersteunende infrastruktuur vir gesondheidsdienste vorm die noodsaaklike grondslag vir die doeltreffende werking van 'n primêre gesondheidsorgstelsel.

As die Wêreldgesondheidsorganisasie se plan van gesondheid vir almal teen die jaar 2000 'n werklikheid moet word, sal verpleegsters saam met ander gesondheidspersoneel hulle houding teenoor die betekenis van die benaming primêre gesondheidsorg moet verander. Hulle sal bereid muet wees om hulle opvattings te verander om primêre, sekondêre en tersiêre voorkoming van siekte op alle gebiede van hulle werk in te sluit. 